\title{
Does mHealth voice messaging work for improving knowledge and practice of maternal and newborn healthcare?
}

\author{
Mahbub Elahi Chowdhury ${ }^{1 *}$ (D), Shafayatul Islam Shiblee ${ }^{1}$ and Heidi E. Jones ${ }^{2}$
}

\begin{abstract}
Background: Aponjon (meaning "near and dear ones"), a mobile phone-based mHealth service, customized voice messages for expectant (6-42 weeks pregnancy) and new mothers (1-52 weeks after delivery) for promotion of recommended healthcare practices. The Aponjon system sent two voice messages per week to subscribers, tailored to the timing during pregnancy or post-partum. The current study is an external evaluation of the effect of Aponjon use on knowledge and behaviors related to maternal and newborn health $(\mathrm{MNH})$ care.
\end{abstract}

Methods: We implemented an observational study of Aponjon users with propensity score matched non-users in Bangladesh. Subscribers with at least 3 months exposure to Aponjon and non-users were interviewed retrospectively on knowledge and practices surrounding MNH. The sample included women with infants $\leq 6$ months (243 users; 369 non-user) for maternal health knowledge and practice indicators and women with infants $>6$ to 12 months old (332 users; 454 non-user) for neonatal health knowledge and practice indicators. Data were analyzed using principal component analysis and categorized as 'high' and 'low' at the median of principal component scores. Interactions between duration of use of Aponjon services and self-reported patterns of receiving and listening to messages were examined to assess the effect on knowledge and practices for $\mathrm{MNH}$.

Results: Women reporting at least 6 months of using Aponjon were approximately 3 times as likely as the nonusers to score high on both maternal healthcare knowledge questions and related practices. Similarly women with at least 6 months of Aponjon exposure were 1.5 times as likely as the non-users to score high on knowledge questions on newborn health. Reporting a good-pattern of Aponjon use (i.e. receiving a minimum of 3 messages per month and listening to all of them) had an even stronger association with knowledge and practices related to MNH care. However, a shorter exposure to Aponjon service (i.e. 3-5 months), despite having a good-pattern of use, did not have an effect on the related outcomes.

Conclusions: The use of Aponjon services for at least 6 months, with a good-pattern of receiving and listening to the messages, was associated with improved knowledge and practices related to $\mathrm{MNH}$ care.

Keywords: Bangladesh, mHealth, Voice messaging, Maternal health, Neonatal health

\footnotetext{
* Correspondence: melahi@icddrb.org

'International Centre for Diarrhoeal Disease Research, Bangladesh (icddr,b),

68 Shaheed Tajuddin Ahmed Sarani, Mohakhali, Dhaka 1212, Bangladesh

Full list of author information is available at the end of the article
}

(c) The Author(s). 2019 Open Access This article is distributed under the terms of the Creative Commons Attribution 4.0 International License (http://creativecommons.org/licenses/by/4.0/), which permits unrestricted use, distribution, and reproduction in any medium, provided you give appropriate credit to the original author(s) and the source, provide a link to the Creative Commons license, and indicate if changes were made. The Creative Commons Public Domain Dedication waiver (http://creativecommons.org/publicdomain/zero/1.0/) applies to the data made available in this article, unless otherwise stated. 


\section{Background}

Extensive use of mobile telephones in many developing countries offers potential for the use of mHealth to disseminate pubilc health information [1]. Recent systematic reviews suggest that mHealth interventions can improve self-management of diabetes, weight loss, physical activity, quitting smoking, and adherence to medication in antiretroviral therapy $[2,3]$. However, to date, few studies have evaluated whether mHealth can improve maternal and newborn health $(\mathrm{MNH})$ among pregnant and postpartum women in low- or middle-income countries [4-9]. A randomized control trial of mHealth in Kenya found a significant increase in attendance of at least four antenatal care visits in the intervention group compared to the control group [4]. Another randomized controlled trial of a mobile phone intervention consisting of short messages combined with a health voucher in Zanzibar found a positive effect on both attending at least four antenatal care visits and using skilled delivery care [5, 6]. A controlled pre-post study in Thailand showed a significant increase in the proportion of children receiving timely vaccination after implementation of a mobile phone-based intervention with automated text message reminders for appointments [7]. A study in Nigeria, examining postnatal care attendance using historic controls from the previous 6 months in the same hospital, found that the intervention group that received text message appointment reminders was $50 \%$ more likely to attend their postnatal care appointments [8]. In terms of nutrition, a quasi-experimental study in Shanghai found that text messages about infant feeding resulted in a significantly higher rate of exclusive breastfeeding at 6 months and a significantly lower rate of the introduction of solid foods before 4 months [9].

Most of these studies assessed the effectiveness of mHealth on maternal and child health in facility settings and used text messages, which have limitations in settings with low literacy [4-9]. The current study aimed to test the effectiveness of an mHealth intervention-Aponjon--which used interactive voice messaging to improve knowledge of $\mathrm{MNH}$ care as well as increase following of recommended $\mathrm{MNH}$ practices in a large community setting in Bangladesh.

\section{Description of Aponjon mHealth service}

Aponjon, a mobile phone-based mHealth service for expectant and new mothers, was developed and implemented by Dnet (a social franchise organization in Bangladesh) in collaboration with Global MAMA (Mobile Alliance for Maternal Action, USA). The goal of the Aponjon mHealth intervention was to disseminate behavior change communication messages quickly and easily to women about the need for prenatal care, dispelling myths and misconceptions around pregnancy and postpartum, building awareness of pregnancy and newborn warning signs, feeding practices for the newborn, postpartum family planning, and nutritional intake to improve $\mathrm{MNH}$ outcomes. Messages were tailored for two separate modules--one during pregnancy and another after delivery. The pregnancy-related module was designed for women during their 6-42 weeks of pregnancy and the module relating to recently delivered women was designed for new mothers, 1-52 week(s) post-partum.

To access the Aponjon services, clients had to subscribe to the service through a registration process by dialing a short code (16227). Dnet, the Aponjon service provider, collaborated with local non-governmental organizations whose health workers promoted Aponjon and assisted with the registration process. Once registered, subscribers received two Interactive Voice Response (IVR) messages per week, tailored to their point in pregnancy (based on self-reported date of last menstrual period or expected date of delivery) or the age of the child.

The Aponjon service was a commercial product and, thus, was not free of charge, except for subscribers from selected marginalized groups. For general subscribers, the service charge was BDT (Bangladeshi Taka) 2.00 per message; for subscribers with income below BDT 4000/ month (half of the minimum wage) or education level below the 5 th grade, the charge was BDT 1.00 per message; and, for subscribers from households headed by a female or a day-laborer, the service was provided free of charge. A subscriber could unsubscribe from the service any time, could listen to messages from previous weeks, and could listen to the same message repeatedly.

\section{Methods}

We conducted a retrospective observational study of users and non-users of Aponjon mHealth service as part of an external evaluation; Dnet developed and implemented the Aponjon mHealth service independently. The study was conducted in four sites: (i) a rural surveillance area (Matlab) of International Centre for Diarrhoeal Disease Research, Bangladesh (icddr,b) which is about $110 \mathrm{~km}$ to the southeast of capital city Dhaka; (ii) a slum (Bhashantek) in Dhaka; (iii) an urban area of a typical district (Brahmanbaria) which is about $111.4 \mathrm{~km}$ to the northeast of Dhaka; and (iv) a rural area in the same district. These sites were chosen purposively. Icddrb's Matlab site was selected as an existing surveillance system facilitated participant selection. We selected the urban slum to test the Aponjon intervention in a population of low socioeconomic status in a metropolitan area. We selected the urban and rural areas of Brahmanbaria to test how the intervention worked in the general population. The study was approved by the Institutional Review Board of icddr,b. 
In each study area, two samples of women were included. Mothers with infants $\leq 6$ months of age were interviewed to assess the effect of Aponjon on knowledge and practice for maternal healthcare during pregnancy and those within $>6$ to 12 month old infants were examined for the effect of the intervention on knowledge and practice of newborn healthcare during the infants' first 6 months of age. Based on the hypothesis that a sufficient threshold of use would be needed to have an effect, we enrolled women with at least 3 months of use of Aponjon services, either during pregnancy (for maternal health outcomes) or within the first 6 months of the post-partum period (for newborn health outcomes).

\section{Data-collection process}

The selection of participants for both sample populations was done in four phases. In Phase I, we identified areas (blocks in urban areas and villages in rural areas) with a minimum Aponjon subscription of $1 \%$ of urban households (Bhashantek slum and urban Brahmanbaria) and $2 \%$ of rural households. Based on these criteria, one slum in Bhashantek (4020 households) and 24 blocks in urban Brahmanbaria (15,852 households), 7 villages in
Matlab (3271 households), and 98 villages in rural Brahmanbaria (43,235 households) were selected.

In Phase II, all households $(n=66,378)$ in the selected areas were visited to identify women with children below 1 year of age and with access to a mobile phone. Accessibility to mobile phone was defined as either owning a mobile phone or having access to a phone of another household member. Women who experienced neonatal death recently or did not have access to a mobile phone were excluded. From visiting 66,378 households, the study identified 3445 mothers with an infant $\leq 6$ months and 3106 mothers with a child $>6$ to 12 months of age. Among mothers with infants $\leq 6$ months of age, we identified 255 who had used Aponjon for at least 3 months during pregnancy and 2970 mothers who had never used it during pregnancy. Similarly, among mothers with $>6$ to 12 month old infants, we identified 345 mothers who had used Aponjon for at least 3 months during the first 6 months post-partum and 2528 mothers who had never used Aponjon during that period (Fig. 1).

In Phase III, we selected all of the mothers identified who had used Aponjon and matched them to two controls from the never users, using propensity score matching (PSM). Propensity scores were estimated based

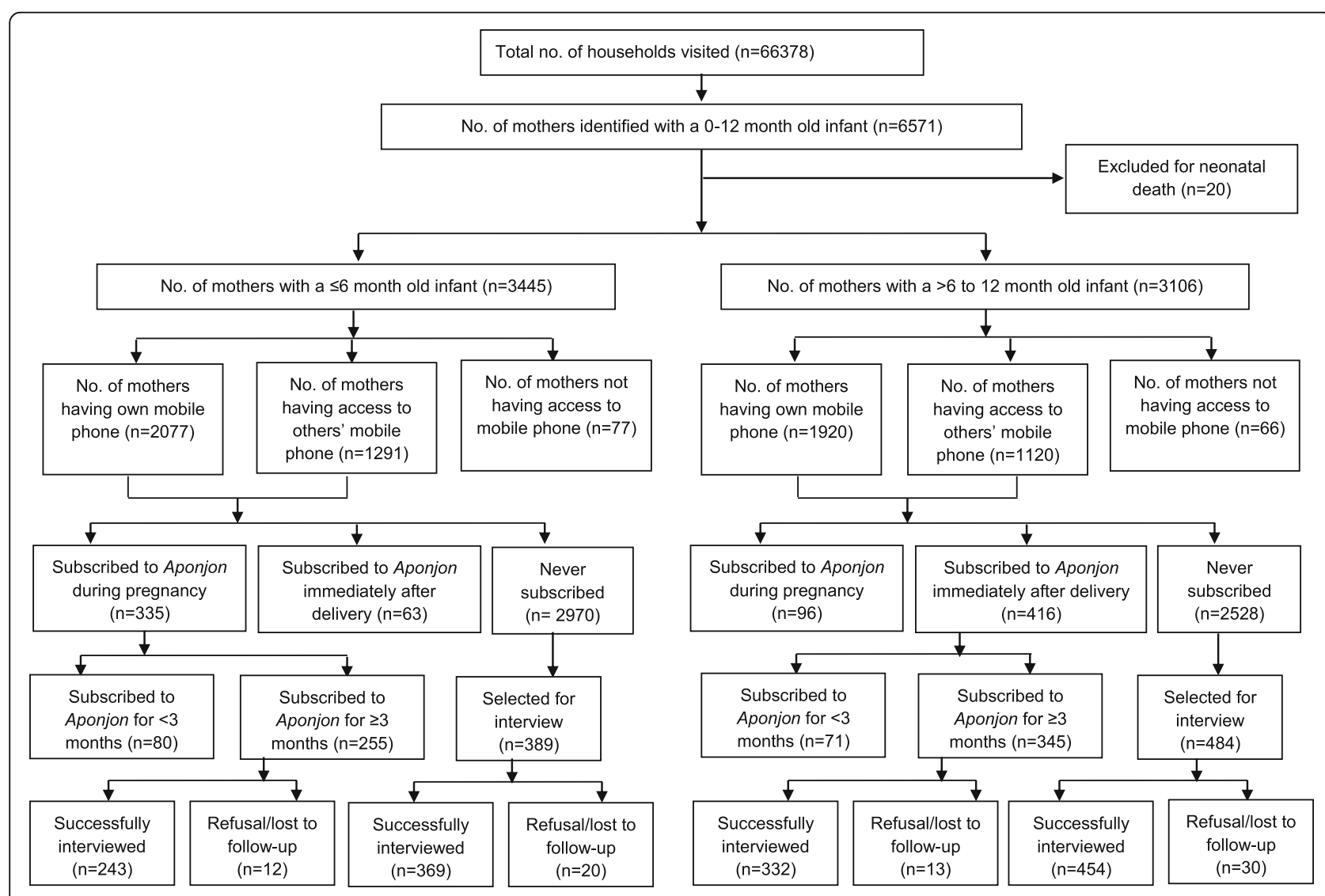

Fig. 1 CONSORT flow diagram for selection of study subjects 
on mother's age, mother's education, father's education, and household wealth index within each of the four sites. Initially, for each exposed participant, two non-exposed participants were selected by applying the nearest neighborhood matching method [10]. Controls selected more than once due to proximity of the propensity score with more than one exposed participant were included only once, resulting in 389 matched controls for the 255 Aponjon users during pregnancy and 484 matched controls for the 345 Aponjon users during the post-partum period.

In Phase IV, all selected participants were re-visited for interviews using pretested structured questionnaires designed to cover the topics covered in the Aponjon messages. Mothers with $\leq 6$ month old infants were asked questions about their knowledge and recommended practices relating to maternal healthcare during the last pregnancy and around the time of delivery. Mothers with $>6$ to 12 month old infants were asked about their knowledge and practices regarding newborn healthcare around the time of delivery through 6 months post-partum. The mothers who had subscribed to Aponjon were also asked about the extent to which they received and listened to the messages. The questionnaires were administered by a team of 32 trained female interviewers divided into four teams under the guidance of four supervisors. Prior to data collection, the full team was intensively trained for 2 weeks on the data-collection tools, including interview techniques. The study investigators closely monitored the data-collection process in the field by making surprise field visits and on-thespot checks of a sample of completed questionnaires. All completed questionnaires were checked for internal validity.

\section{Data analysis}

We estimated the effect of being exposed to Aponjon services on four different outcome domains, based on the messages of the services: (i) knowledge of maternal healthcare (22 indicators); (ii) behaviors relating to maternal healthcare (19 indicators); (iii) knowledge of newborn healthcare (23 indicators); and (iv) behaviors relating to newborn health (12 indicators; see Additional file 1 for full questionnaire). For each domain, a composite dichotomous outcome measure was created using principal component analysis with orthogonal rotation of related indicators. We dichotomized the principal component score for each domain at the median. We also assessed the dose-response effect by examining the association of outcome variables with the ordinal exposure variable at $0,3-5$ and $\geq 6$ months of use of Aponjon services. We further tested for interaction between duration of use of Aponjon services and a dichotomous measure of 'pattern of receiving and listening to the messages'. We defined this pattern as a "good pattern" for women who self-reported having received at least 3 messages per month and carefully listening to most of the messages or as a "poor pattern" for women who reported having received fewer than 3 messages per month and/or not listening to most of the messages carefully. For each domain, we present bivariate and multivariable logistic regression, adjusting for a priori hypothesized confounders not included in the propensity score (ownership of mobile phone as an indicator of socioeconomic position, rural vs. urban residence, and exposure to other forms of media) as well as clustering at the block/village levels. We used a critical alpha value of 0.05 to determine statistical significance.

\section{Results}

Of the 6551 mothers with infants under 1 year old, $61.0 \%(3997 / 6551)$ had their own mobile phone, 36.8\% (2411/6551) had access to other's phones, and 2.2\% (143/6551) did not have any access to a mobile phone (Fig. 1). Overall, among mothers with infants $\leq 6$ months of age with access to a mobile phone, only 9.9\% (335/ 3368) subscribed to Aponjon during pregnancy and $7.6 \%$ (255/3368) used the service for at least 3 months. Among mothers with infants $>6$ to 12 months old, only $13.7 \%$ (416/3040) subscribed to Aponjon within the first 6 months of delivery, and $11.3 \%$ (345/3040) used the service for at least 3 months during that period.

Response rates in all groups were high: 95.3\% (243/ 255) of mothers who used Aponjon services during pregnancy and $96.2 \%(332 / 345)$ of mothers who used Aponjon post partum were successfully interviewed. The rate of successful interviews in the respective control groups were $94.9 \%(369 / 389)$ and $93.8 \%$ (454/484) respectively (Fig. 1).

As shown in Table 1, about four-fifths of the participants lived in rural areas and one-fifth in an urban area. The slum represented only about $1.0 \%$ of participants. The majority of participants in each group were between 20 and 29 years of age, had at least primary education, belonged to the top two socioeconomic quintiles, and had exposure to at least one form of mass media (Table 1). After PSM, the background characteristics of the participants were similar between the intervention and control groups for both categories of women (with infants $\leq 6$ months and $>6$ to 12 months), except for ownership of mobile phones. In both groups, a relatively higher proportion of Aponjon service-users owned a mobile phone compared to non-users.

\section{Use of Aponjon services}

Not all Aponjon service-users received all 8 messages per month as sent by Aponjon. Overall, 84.3\% (485/575) of users said that they had received at least 3 messages per month. Of them 54.4 and $29.9 \%$ had received 3-5 and 6-8 messages per month respectively. The remaining 
Table 1 Comparison of background characteristics between the propensity score matched users and non-users of Aponjon services

\begin{tabular}{|c|c|c|c|c|c|c|}
\hline \multirow[t]{2}{*}{ Characteristics } & \multicolumn{3}{|c|}{ Mothers of infants $\leq 6$ months of age } & \multicolumn{3}{|c|}{ Mothers of infants $>6$ to 12 months of age } \\
\hline & $\begin{array}{l}\text { Number of users } \\
(\%)\end{array}$ & $\begin{array}{l}\text { Number of non users } \\
(\%)\end{array}$ & $\overline{p \text {-value }}$ & $\begin{array}{l}\text { Number of users } \\
(\%)\end{array}$ & $\begin{array}{l}\text { Number of non users } \\
(\%)\end{array}$ & $\overline{p \text {-value }}$ \\
\hline \multicolumn{7}{|l|}{ Study areas } \\
\hline Bhasantek slum in Dhaka & $2(0.8 \%)$ & $4(1.1 \%)$ & 0.48 & $4(1.2 \%)$ & $4(0.9 \%)$ & 0.18 \\
\hline Urban Brahmanbaria & $33(13.6 \%)$ & $67(18.2 \%)$ & & $40(12.1 \%)$ & $80(17.6 \%)$ & \\
\hline Rural Brahmanbaria & $201(82.7 \%)$ & $287(77.8 \%)$ & & $283(85.2 \%)$ & $362(79.7 \%)$ & \\
\hline Matlab field site of icddr,b & $7(2.9 \%)$ & $11(2.9 \%)$ & & $5(1.5 \%)$ & $8(1.8 \%)$ & \\
\hline \multicolumn{7}{|l|}{ Mother's age } \\
\hline$<19$ years & $35(14.4 \%)$ & $57(15.5 \%)$ & 0.98 & $41(12.4 \%)$ & 65 (14.3\%) & 0.63 \\
\hline 20-24 years & $84(34.6 \%)$ & $125(33.9 \%)$ & & $122(36.8 \%)$ & $169(37.2 \%)$ & \\
\hline $25-29$ years & $73(30.0 \%)$ & $113(30.6 \%)$ & & $108(32.5 \%)$ & $130(28.6 \%)$ & \\
\hline 30 years and above & $51(21.0 \%)$ & $74(20.1 \%)$ & & $61(18.4 \%)$ & 90 (19.8\%) & \\
\hline \multicolumn{7}{|l|}{ Mother's education } \\
\hline Incomplete primary & $35(14.4 \%)$ & 55 (14.9\%) & 0.98 & $40(12.1 \%)$ & 64 (14.1\%) & 0.55 \\
\hline Primary & $69(28.4 \%)$ & $109(29.5 \%)$ & & $105(31.6 \%)$ & $153(33.7 \%)$ & \\
\hline Secondary & $86(35.4 \%)$ & $128(34.7 \%)$ & & $113(34.0 \%)$ & $152(33.5 \%)$ & \\
\hline Higher & $53(21.8 \%)$ & 77 (20.9\%) & & $74(22.3 \%)$ & 85 (18.7\%) & \\
\hline \multicolumn{7}{|l|}{ Father's education } \\
\hline Incomplete primary & $62(25.5 \%)$ & $103(27.9 \%)$ & 0.89 & $71(21.4 \%)$ & $96(21.2 \%)$ & 0.99 \\
\hline Primary & $54(22.2 \%)$ & 75 (20.3\%) & & $105(31.6 \%)$ & $149(32.8 \%)$ & \\
\hline Secondary & 75 (30.9\%) & $111(30.1 \%)$ & & 79 (23.8\%) & $105(23.1 \%)$ & \\
\hline Higher & $52(21.4 \%)$ & $80(21.7 \%)$ & & 77 (23.2\%) & $104(22.9 \%)$ & \\
\hline \multicolumn{7}{|l|}{ Household asset quintiles } \\
\hline Lowest & $26(10.7 \%)$ & 39 (10.6\%) & 0.56 & $26(7.8 \%)$ & $46(10.1 \%)$ & 0.48 \\
\hline Second & $42(17.3 \%)$ & $68(18.4 \%)$ & & 65 (19.6\%) & 87 (19.2\%) & \\
\hline Middle & 49 (20.2\%) & $93(25.2 \%)$ & & 69 (20.8\%) & 87 (19.2\%) & \\
\hline Fourth & $58(23.9 \%)$ & $82(22.2 \%)$ & & $83(25.0 \%)$ & $130(28.6 \%)$ & \\
\hline Highest & $68(27.9 \%)$ & 87 (23.6\%) & & 89 (26.8\%) & $104(22.9 \%)$ & \\
\hline \multicolumn{7}{|l|}{ Ownership of mobile phone } \\
\hline Used others' phone & $74(30.5 \%)$ & $141(38.2 \%)$ & 0.05 & $81(24.4 \%)$ & $173(38.1 \%)$ & 0.00 \\
\hline Had own phone & $169(69.6 \%)$ & $228(61.8 \%)$ & & $251(75.6 \%)$ & $281(61.9 \%)$ & \\
\hline \multicolumn{7}{|l|}{ Exposure to mass media } \\
\hline No exposure & $76(31.3 \%)$ & $126(34.15 \%)$ & 0.65 & $100(30.1 \%)$ & $162(35.7 \%)$ & 0.26 \\
\hline Exposure to 1 form of media & $133(54.7 \%)$ & $199(53.9 \%)$ & & $187(56.3 \%)$ & $234(51.5 \%)$ & \\
\hline $\begin{array}{l}\text { Exposure to } \geq 2 \text { forms of } \\
\text { media }\end{array}$ & $34(13.9 \%)$ & $44(11.9 \%)$ & & 45 (13.6\%) & $58(12.8 \%)$ & \\
\hline
\end{tabular}

$15.7 \%(90 / 575)$ reported receiving only 1-2 messages per month. Three major reasons cited for not receiving the phone call were due to household chores (72\%), someone else owning the mobile phone (48\%), and airtime cost for Aponjon services (10\%). Upon receiving the call, not all women carefully listened to the messages. Only about 35.5\% (204/575) women said that they had carefully listened to all of the messages they had receivedand the rest $64.5 \%$ (371/575) listened to only some of the messages. Thirty-two percent (184/ 575) of Aponjon subscribers who had received at least 3 messages per month and listened to all the messages carefully were defined as having a 'good pattern of receiving and listening to the messages'. The remaining $68.0 \%(391 / 575)$ who had either received < 3 messages per month or not carefully listened to all of the messages were defined as having a 'poor pattern of receiving and listening to the messages'. 


\section{Effect of Aponjon on individual knowledge and behavior indicators}

Table 2 demonstrates the crude association of the use of Aponjon services with each of the indicators in the four domains. For maternal health knowledge, 7 (41\%) indicators (correct timing of seeking 4 different antenatal cares (ANCs), place of ANC, importance of blood grouping, symptoms of eclampsia, pregnancy danger signs, place of seeking postnatal care (PNC), and duration of birth spacing) out of 22 were higher among Aponjon serviceusers. For behaviors relating to maternal healthcare, 8 $(42 \%)$ indicators (seeking ANC from skilled care providers, number of ANC visits made, receiving ANC at the recommended gestational period, number of diagnostic tests done, taking initiative for different birth preparedness components, taking iron-folic acid during pregnancy, taking vitamin A capsules after delivery, taking vitamin A capsules within 1-7 day(s) of delivery) out of 19, were significantly associated with the use of Aponjon services. Similarly, for the knowledge of newborn healthcare, 7 out of 23 (30\%) indicators (knowledge on symptoms of infected umbilical cord, correctly reporting on days of delayed bathing of the newborn, benefits of feeding colostrum, benefits of exclusive breastfeeding, understanding if sufficient breast-milk had been sucked by the baby, types of diseases preventable by immunization, and time of seeking care for diarrhea of the baby) were positively associated with the use of Aponjon services. In addition, in each of these three domains, a number of indicators (responses on reasons for Tetanus Toxoid vaccination, correct reporting on recommended lying position during pregnancy, responses on birth preparedness components, correct reporting on recommended number (four) of postpartum care visits, receiving care from facilities for complications during pregnancy, responses about the place of vaccination, responses on type of care to be given for diarrhea) were also of borderline significance $(p<0.10)$. Surprisingly, for behaviors relating to newborn healthcare, none of the 12 indicators studied were different between users of Aponjon services and non-users.

\section{Effect of Aponjon on composite knowledge and behavior measures}

As seen in Table 3, after adjustment of hypothesized confounders, 3-5 months of the use of Aponjon services was not associated with increased maternal healthcare knowledge as a composite score (Adjusted OR, aOR: $1.20,95 \%$ CI $0.80,1.81$ ) or practices (aOR: $1.18,95 \%$ CI $0.81,1.72)$ compared to non-users. However, at least 6 months of Aponjon use was associated with a 3 times higher likelihood of a high maternal healthcare knowledge score $(\mathrm{aOR}=2.83,95 \%$ CI 1.57 , $5.09)$ and recommended related practices $(\mathrm{aOR}=3.38$,
95\% CI 1.77, 6.48). Further, women who reported a 'good pattern of receiving and listening to messages' were about twice as likely to have a higher knowledge score $(\mathrm{aOR}=2.00,95 \% \mathrm{CI} 1.17,3.37)$ and related practices $(\mathrm{aOR}=1.96,95 \%$ CI 1.09, 3.51) for maternal healthcare compared to non-users.

When we further examined the duration of use with the 'pattern of receiving and listening to messages' of Aponjon, 3-5 months of use of Aponjon services, despite having a 'good pattern of receiving and listening to messages' had no effect on knowledge and practice surrounding maternal healthcare. However, at least 6 months of Aponjon service-use with 'good pattern of receiving and listening to messages' increased the odds of high knowledge by about 3 times $(\mathrm{aOR}=2.97,95 \% \mathrm{CI}$ $1.09,8.09)$. as well as practices $(\mathrm{aOR}=2.66,95 \% \mathrm{CI} 0.92$, 7.62, Table 3).

As seen in Table 4, our analysis on the effect of Aponjon services on newborn healthcare showed that 35 months of use was not associated with increased knowledge ( $\mathrm{aOR}=1.19,95 \% \mathrm{CI} 0.67,2.12$ ), while use for $\geq 6$ months was associated with increased knowledge $(\mathrm{aOR}=1.46,95 \%$ CI 1.05, 2.03). Duration of use of Aponjon services was not associated with newborn practices. However, at least 6 months of use with a 'good pattern of receiving and listening to messages' was associated with higher scores for both knowledge $(\mathrm{aOR}=$ $1.63,95 \% \mathrm{CI} 1.02,2.61)$ and practices $(\mathrm{aOR}=1.63,95 \%$ CI 1.06, 2.51) related to newborn healthcare.

\section{Discussion}

Almost all women either owned a personal cell phone (61\%), and/or had access to a household member's phone $(37 \%)$. However, in the study areas, only about 8 and $11 \%$ of the respondents used Aponjon for at least 3 months during pregnancy and early motherhood, respectively. Our study demonstrates that subscribers to the Aponjon mHealth intervention had higher knowledge and positive self-reported behaviors for improved maternal health than non-subscribers. Mothers who subscribed to Aponjon for at least 6 months and reported receiving and listening to messages had better knowledge and reported more recommended behaviors for both maternal and newborn healthcare compared to non-users.

Most previous studies that have examined the impact of mHealth services have focused on selected components of $\mathrm{MNH}$ care, like ANC [4, 5, 7], PNC, and immunization coverage [8]. All of these studies were facility-based and, thus, might not be generalizable to community settings. Moreover, all of these studies used text messages to remind mothers of an upcoming routine check-up or vaccination for their children. Conversely, we, for the first time, examined the effectiveness 
Table 2 Variations in outcome indicators of knowledge and practices for maternal and newborn health for users and non users of Aponjon services

\begin{tabular}{|c|c|c|c|}
\hline $\begin{array}{l}\text { Knowledge of maternal healthcare } \\
\text { (users vs. non-users, p-value) }\end{array}$ & $\begin{array}{l}\text { Practice of maternal healthcare } \\
\text { (users vs. non-users, p-value) }\end{array}$ & $\begin{array}{l}\text { Knowledge of newborn health } \\
\text { care (users vs non-users, p-value) }\end{array}$ & $\begin{array}{l}\text { Practice of newborn health care } \\
\text { (users vs non-users, } p \text { value) }\end{array}$ \\
\hline $\begin{array}{l}\% \text { of women who correctly reported } \\
\text { minimum required number (four) of } \\
\text { ANC visits ( } 23.46 \text { vs. } 18.70, p=0.15 \text { ) }\end{array}$ & $\begin{array}{l}\% \text { of women who had ANC from } \\
\text { skilled care providers during the last } \\
\text { pregnancy }(88.07 \text { vs. } 79.40, p<0.01)\end{array}$ & $\begin{array}{l}\text { Mean no. of correct responses (out } \\
\text { of } 2 \text { ) on knowledge of umbilical cord } \\
\text { care of the newborn ( } 0.08 \mathrm{vs} .0 .05 \text {, } \\
p=0.19 \text { ) }\end{array}$ & $\begin{array}{l}\% \text { of mothers who delayed bathing } \\
\text { the newborn ( } 54.82 \text { vs. } 54.19 \text {, } \\
p=0.86 \text { ) }\end{array}$ \\
\hline $\begin{array}{l}\text { Mean no. of correct responses (out } \\
\text { of } 4 \text { ) on time of four ANC visits }(0.66 \\
\text { vs. } 0.44, p=0.00 \text { ) }\end{array}$ & $\begin{array}{l}\text { Mean no. of ANC received ( } 2.48 \text { vs. } \\
2.13, p<0.01)\end{array}$ & $\begin{array}{l}\% \text { of mothers who correctly reported } \\
\text { on days for detachment of umbilical } \\
\text { cord }(64.76 \text { vs } 69.16, p=0.19)\end{array}$ & $\begin{array}{l}\% \text { of mothers who fed colostrum as } \\
\text { the first food to the newborn }(81.93 \\
\text { vs. } 80.18, p=0.54)\end{array}$ \\
\hline $\begin{array}{l}\text { Mean no. of correct responses (out } \\
\text { of } 3 \text { ) on place of ANC visits ( } 1.44 \text { vs. } \\
1.30, p=0.00 \text { ) }\end{array}$ & $\begin{array}{l}\text { Mean no. of correct responses (out } \\
\text { of } 4 \text { ) for receiving ANC at } \\
\text { recommended time during } \\
\text { pregnancy }(0.56 \text { vs. } 0.32, p<0.01 \text { ) }\end{array}$ & $\begin{array}{l}\text { Mean no. of correct responses (out } \\
\text { of } 3 \text { ) on knowledge of symptoms of } \\
\text { infected umbilical cord }(1.17 \mathrm{vs.} \\
1.02, \mathrm{p}<0.01)\end{array}$ & $\begin{array}{l}\text { \% of mothers who breastfed within } 1 \\
\text { hour of delivery ( } 73.19 \text { vs. } 72.69 \text {, } \\
p=0.88 \text { ) }\end{array}$ \\
\hline $\begin{array}{l}\% \text { of women who correctly reported } \\
\text { on importance of blood grouping } \\
(68.72 \text { vs } 60.70, p=0.04)\end{array}$ & $\begin{array}{l}\text { Mean no. of diagnostic tests (out of } \\
5 \text { ) taken during pregnancy }(2.33 \mathrm{vs} \text {. } \\
1.98, p<0.01 \text { ) }\end{array}$ & $\begin{array}{l}\% \text { of mothers who correctly reported } \\
\text { on days of delayed bathing of the } \\
\text { newborn }(57.53 \text { vs. } 48.24, p=0.01)\end{array}$ & $\begin{array}{l}\% \text { of mothers who exclusively } \\
\text { breastfed their babies up to } 6 \\
\text { months }(58.43 \text { vs. } 54.85, p=0.32 \text { ) }\end{array}$ \\
\hline $\begin{array}{l}\% \text { of women who correctly reported } \\
\text { on type of TT to be taken during } \\
\text { pregnancy }(72.84 \text { vs. } 68.29, p=0.22)\end{array}$ & $\begin{array}{l}\% \text { of women who had blood grouping } \\
\text { during pregnancy ( } 50.62 \text { vs. } 46.34 \text {, } \\
p=0.30 \text { ) }\end{array}$ & $\begin{array}{l}\% \text { of mothers who correctly reported } \\
\text { on type of first food (colostrum) of } \\
\text { the newborn ( } 92.47 \text { vs. } 92.07 \text {, } \\
p=0.84 \text { ) }\end{array}$ & $\begin{array}{l}\% \text { of mothers who started weaning at } \\
6-7 \text { months of age of the babies } \\
(81.93 \text { vs. } 77.97, p=0.17)\end{array}$ \\
\hline $\begin{array}{l}\text { Mean no. of correct responses (out } \\
\text { of } 2 \text { ) on reasons for TT vaccination } \\
(1.13 \text { vs. } 1.02, p=0.07 \text { ) }\end{array}$ & $\begin{array}{l}\% \text { of women who had recommended } \\
\text { number of TT shots for pregnancy } \\
(49.79 \text { vs. } 55.56, p=0.16)\end{array}$ & $\begin{array}{l}\text { Mean no. of correct responses (out } \\
\text { of } 3 \text { ) on mothers' knowledge about } \\
\text { benefits of feeding colostrum ( } 1.16 \\
\text { vs. } 1.02, p<0.01 \text { ) }\end{array}$ & $\begin{array}{l}\text { Mean no. of correct responses (out } \\
\text { of } 3 \text { ) on types of food given for } \\
\text { weaning ( } 1.68 \text { vs. } 1.68, p=0.94)\end{array}$ \\
\hline $\begin{array}{l}\% \text { of women who correctly reported } \\
\text { on time of TT vaccination during } \\
\text { pregnancy ( } 55.97 \text { vs. } 57.18, p=0.77)\end{array}$ & $\begin{array}{l}\% \text { of women who received care from } \\
\text { facilities for complications during } \\
\text { pregnancy }(n=269) \text { ( } 96.33 \text { vs. } 90.63 \\
p=0.07)\end{array}$ & $\begin{array}{l}\% \text { of mothers who correctly reported } \\
\text { on duration for exclusive } \\
\text { breastfeeding ( } 93.37 \text { vs. } 90.75 \text {, } \\
p=0.18 \text { ) }\end{array}$ & $\begin{array}{l}\% \text { of mothers who started } \\
\text { vaccination of babies at } 40-45 \text { days } \\
(39.76 \text { vs. } 37.67, p=0.55)\end{array}$ \\
\hline $\begin{array}{l}\text { Mean no. of correct responses (out } \\
\text { of } 2 \text { ) for need of additional food } \\
\text { intake (1.67 vs. } 1.61, p=0.19)\end{array}$ & $\begin{array}{l}\text { Mean no. of correct responses (out } \\
\text { of } 6) \text { for taking initiatives for different } \\
\text { birth preparedness components } \\
(2.67 \text { vs. } 2.45, p=0.04)\end{array}$ & $\begin{array}{l}\text { Mean no. of correct responses (out } \\
\text { of } 4 \text { ) on knowledge of benefits of } \\
\text { exclusive breastfeeding ( } 2.11 \text { vs. } \\
1.85, p<0.01 \text { ) }\end{array}$ & $\begin{array}{l}\text { Mean no. (out of } 3 \text { ) of vaccines of } \\
\text { different types given to the newborn } \\
(1.80 \text { vs. } 1.58, p=0.13)\end{array}$ \\
\hline $\begin{array}{l}\% \text { of women who correctly reported } \\
\text { on minimum required hours of rest to } \\
\text { be taken during daytime ( } 59.26 \mathrm{vs.} \\
57.18, p=0.48)\end{array}$ & $\begin{array}{l}\% \text { of women who had skilled delivery } \\
\text { care (facility or skilled attendance at } \\
\text { home) }(59.26 \text { vs. } 54.47, p=0.24)\end{array}$ & $\begin{array}{l}\text { Mean no. of correct responses (out } \\
\text { of } 4 \text { ) on understanding having } \\
\text { sufficient breast-milk by the baby } \\
(1.18 \text { vs. } 1.06, p=0.02 \text { ) }\end{array}$ & $\begin{array}{l}\text { Mean no. of correct responses (out } \\
\text { of } 2) \text { on practice of umbilical cord } \\
\text { care of the newborn ( } 0.05 \text { vs. } 0.07 \text {, } \\
p=0.23)\end{array}$ \\
\hline $\begin{array}{l}\% \text { of women who correctly reported } \\
\text { on recommended lying position } \\
\text { during pregnancy ( } 32.10 \text { vs. } 25.47 \text {, } \\
p=0.07 \text { ) }\end{array}$ & $\begin{array}{l}\% \text { of women who had adequate } \\
\text { intake of water during pregnancy } \\
\text { (53.91 vs. } 50.95, p=0.47 \text { ) }\end{array}$ & $\begin{array}{l}\% \text { of mothers who correctly reported } \\
\text { on initiation of breastfeeding after } \\
\text { delivery ( } 91.57 \text { vs. } 91.19, p=0.85)\end{array}$ & $\begin{array}{l}\% \text { of mothers who reported seeking } \\
\text { care for newborn health } \\
\text { complications }(n=449)(78.92 \text { vs. } \\
74.62, p=0.50)\end{array}$ \\
\hline $\begin{array}{l}\text { Mean no. of correct responses (out } \\
\text { of } 2 \text { ) on reasons for lying on the left } \\
\text { side }(0.13 \text { vs. } 0.09, p=0.24)\end{array}$ & $\begin{array}{l}\text { Mean no. of correct responses (out } \\
\text { of } 4) \text { for nutritious food intake during } \\
\text { pregnancy }(2.70 \text { vs. } 2.70, p=0.96)\end{array}$ & $\begin{array}{l}\% \text { of mothers who reported correctly } \\
\text { on age of the baby for initiation of } \\
\text { weaning ( } 96.08 \text { vs. } 94.05, p=0.20)\end{array}$ & $\begin{array}{l}\% \text { of mothers who talked to baby } \\
(97.90 \text { vs. } 98.68, p=0.40)\end{array}$ \\
\hline $\begin{array}{l}\text { Mean no. of correct responses (out } \\
\text { of } 3 \text { ) on symptoms of eclampsia } \\
(0.42 \text { vs. } 0.30, p=0.02)\end{array}$ & $\begin{array}{l}\% \text { of women who had iron-folic acid } \\
\text { during pregnancy ( } 63.79 \text { vs. } 55.56 \text {, } \\
p=0.04 \text { ) }\end{array}$ & $\begin{array}{l}\% \text { of mothers who correctly reported } \\
\text { on age of the baby for polio vaccine } \\
(5.42 \text { vs. } 4.63, p=0.61)\end{array}$ & $\begin{array}{l}\% \text { of mothers who played with } \\
\text { babies with colorful toys ( } 97.00 \text { vs. } \\
98.46, p=0.16 \text { ) }\end{array}$ \\
\hline $\begin{array}{l}\text { Mean no. of correct responses (out } \\
\text { of } 9 \text { ) on pregnancy danger signs } \\
(2.40 \text { vs. } 2.16, p=0.02)\end{array}$ & $\begin{array}{l}\% \text { of women who had at least } 2 \mathrm{hrs} \text {. } \\
\text { of rest in daytime during pregnancy } \\
(47.33 \text { vs. } 48.24, p=0.83 \text { ) }\end{array}$ & $\begin{array}{l}\text { Mean no. of correct responses (out } \\
\text { of } 2 \text { ) about the place of vaccination } \\
(1.66 \text { vs. } 1.60, p=0.09)\end{array}$ & \\
\hline $\begin{array}{l}\text { Mean no. of correct responses (out } \\
\text { of } 2 \text { ) on place of care for } \\
\text { complications ( } 1.04 \text { vs. } 1.05, p=0.84 \text { ) }\end{array}$ & $\begin{array}{l}\% \text { of women who had less daily } \\
\text { activities during pregnancy } \\
\text { compared to before ( } 56.38 \text { vs. } 55.56 \text {, } \\
p=0.84 \text { ) }\end{array}$ & $\begin{array}{l}\text { Mean no. of correct responses (out } \\
\text { of } 7 \text { ) on types of diseases } \\
\text { preventable by immunization ( } 1.88 \\
\text { vs. } 1.61, p=0.04 \text { ) }\end{array}$ & \\
\hline $\begin{array}{l}\text { Mean no. of correct responses (out } \\
\text { of } 3 \text { ) on indications of labor pain } \\
(1.83 \text { vs. } 1.82, p=0.93 \text { ) }\end{array}$ & $\begin{array}{l}\text { Mean no. of PNC visits (out of } 4 \text { ) } \\
\text { attended ( } 0.87 \text { vs. } 0.92, p=0.66)\end{array}$ & $\begin{array}{l}\text { Mean no. of correct responses (out } \\
\text { of } 2 \text { ) about color of babies' stool for } \\
\text { seeking care }(0.72 \text { vs. } 0.65, p=0.14)\end{array}$ & \\
\hline $\begin{array}{l}\text { Mean no. of correct responses (out } \\
\text { of } 3 \text { ) on place of skilled delivery } \\
(1.28 \text { vs. } 1.24, p=0.15 \text { ) }\end{array}$ & $\begin{array}{l}\text { Mean no. of correct responses (out } \\
\text { of } 4 \text { ) for receiving PNC at } \\
\text { recommended postpartum period } \\
(0.19 \text { vs. } 0.13, p=0.14)\end{array}$ & $\begin{array}{l}\text { Mean no. of correct responses (out } \\
\text { of } 2 \text { ) on type of care to be given for } \\
\text { diarrhea ( } 1.06 \text { vs. } 1.00, p=0.09 \text { ) }\end{array}$ & $\begin{array}{l}\text { Significant } \\
\text { Borderline significant }\end{array}$ \\
\hline $\begin{array}{l}\text { Mean no. of correct responses (out } \\
\text { of } 7 \text { ) on birth preparedness } \\
\text { components }(3.17 \text { vs. } 2.96, p=0.06)\end{array}$ & $\begin{array}{l}\% \text { of women who had PNC from } \\
\text { skilled care provider }(39.09 \text { vs. } \\
40.65, p=0.70)\end{array}$ & $\begin{array}{l}\text { Mean no. of correct responses (out } \\
\text { of } 2 \text { ) on time of seeking care for } \\
\text { diarrhea of the baby ( } 0.31 \text { vs. } 0.21 \text {, } \\
\text { p<0.01) }\end{array}$ & Non-significant \\
\hline $\begin{array}{l}\% \text { of women who correctly reported } \\
\text { on need for postpartum care }(72.43 \\
\text { vs. } 71.54, p=0.81)\end{array}$ & $\begin{array}{l}\% \text { of women who had vitamin } A \\
\text { capsules after delivery }(54.73 \mathrm{vs} \text {. } \\
42.01, p<0.01)\end{array}$ & $\begin{array}{l}\% \text { of mothers who correctly reported } \\
\text { on age of the babies with jaundice } \\
(9.34 \text { vs. } 12.78, p=0.13)\end{array}$ & \\
\hline $\begin{array}{l}\% \text { of women who correctly reported } \\
\text { on recommended number }(4) \text { of } \\
\text { postpartum care visits }(9.05 \text { vs. } 5.15 \text {, } \\
p=0.05)\end{array}$ & $\begin{array}{l}\% \text { of women who had vitamin A } \\
\text { capsules within } 1-7 \text { day(s) of delivery } \\
(24.28 \text { vs. } 15.99, p=0.01)\end{array}$ & $\begin{array}{l}\text { Mean no. of correct responses (out } \\
\text { of } 5 \text { ) on signs of a healthy baby }(1.48 \\
\text { vs. } 1.45, p=0.51)\end{array}$ & \\
\hline $\begin{array}{l}\text { Mean no. of correct responses (out } \\
\text { of } 4 \text { ) for time of } 4 \text { PNC visits }(0.16 \\
\text { vs. } 0.14, p=0.56 \text { ) }\end{array}$ & & $\begin{array}{l}\text { Mean no. of correct responses (out } \\
\text { of } 11 \text { ) on types of health } \\
\text { complications of babies ( } 2.8 \text { vs. } 2.8 \text {, } \\
p=0.99 \text { ) }\end{array}$ & \\
\hline $\begin{array}{l}\text { Mean no. of correct responses (out } \\
\text { of } 3 \text { ) on place of PNC visit ( } 0.89 \text { vs. } \\
0.79, p=0.04)\end{array}$ & & $\begin{array}{l}\text { Mean no. of correct responses (out } \\
\text { of } 2 \text { ) on place of seeking care for } \\
\text { newborn health complications ( } 1.05 \\
\text { vs. } 1.05, p=0.88 \text { ) }\end{array}$ & \\
\hline \multirow[t]{2}{*}{$\begin{array}{l}\% \text { of women who correctly reported } \\
\text { on birth spacing (minimum } 2 \text { yrs) } \\
\text { ( } 98.34 \text { vs. } 94.85, p=0.03)\end{array}$} & & $\begin{array}{l}\% \text { of mothers who correctly reported } \\
\text { on age of the baby able to sit by } \\
\text { itself ( } 60.24 \text { vs. } 6542, p=0.14 \text { ) }\end{array}$ & \\
\hline & & $\begin{array}{l}\% \text { of mothers who correctly reported } \\
\text { on } 3-4 \text { months age of the baby able } \\
\text { to steadily hold up head ( } 65.36 \text { vs. } \\
70.26, p=0.15)\end{array}$ & \\
\hline
\end{tabular}




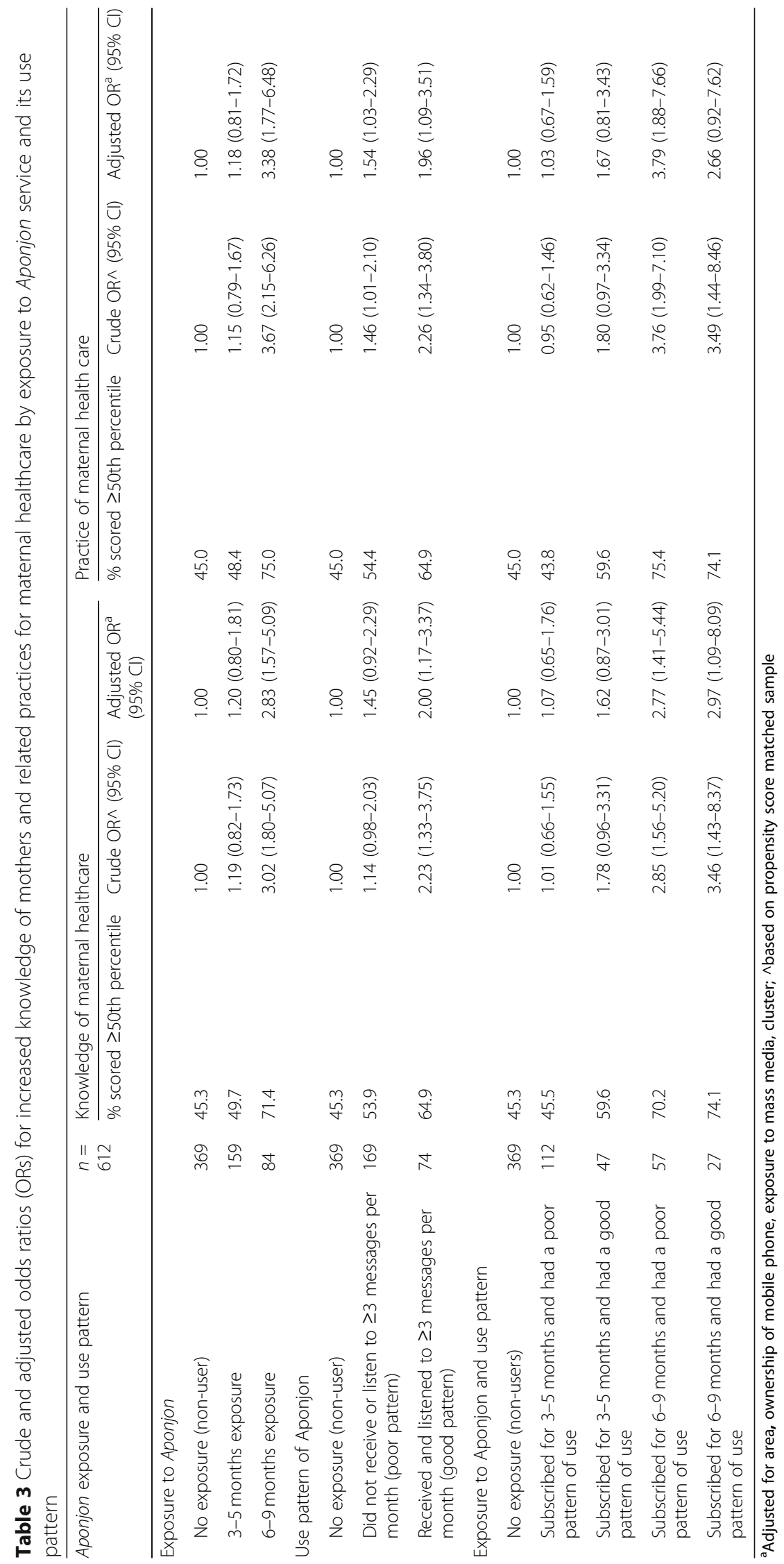




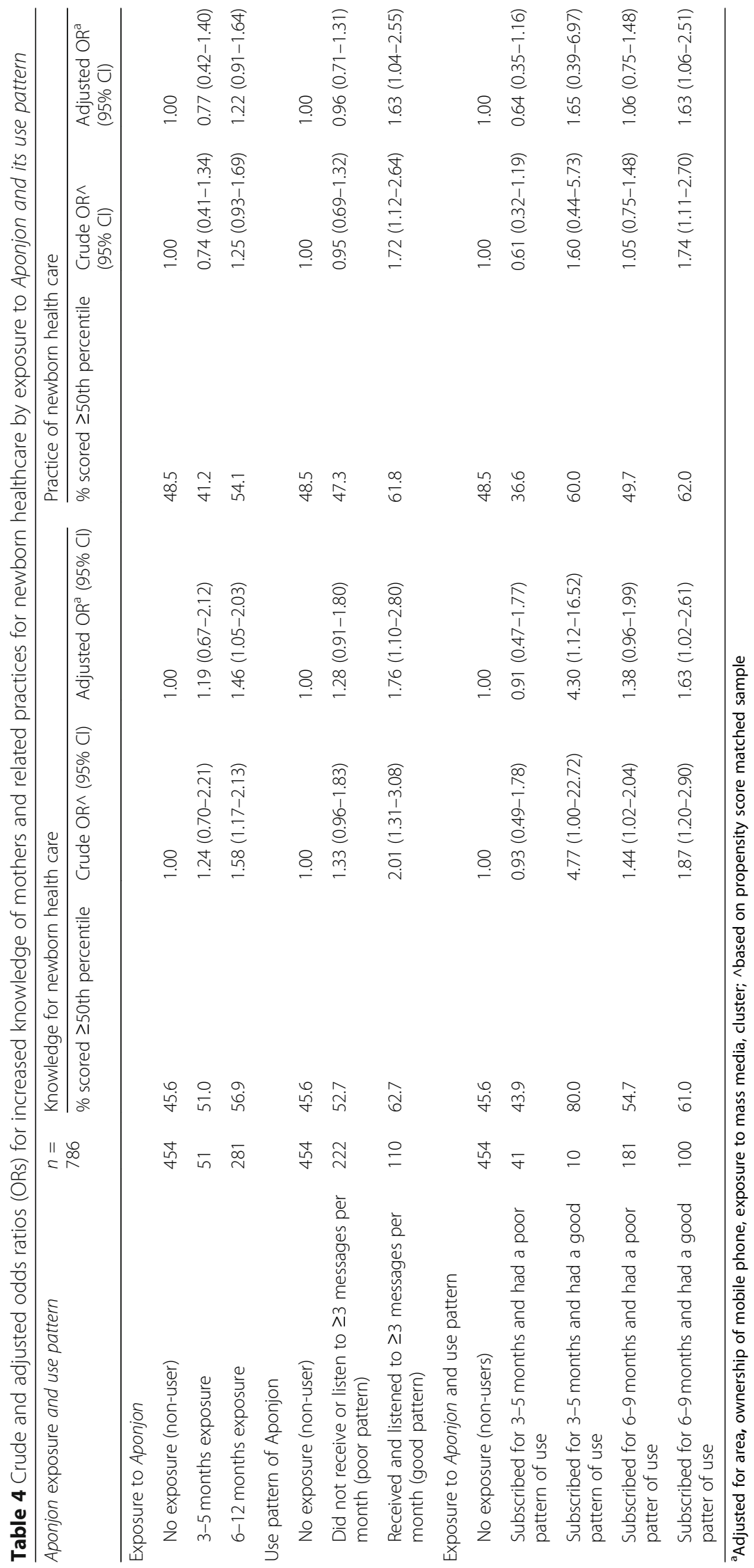


of a package of voice messages to increase knowledge and promote good practices in four different domains of $\mathrm{MNH}$ care in community settings. We also examined how using the mHealth service for an extended period and having a good pattern of use impacted its effect.

Our findings showed that exposure to Aponjon was associated with better knowledge of mothers about when and where to access ANC services. This finding is consistent with recent studies which found that mHealth services increased antenatal care attendance $[4,6,11]$.

Our study also demonstrated that Aponjon can increase knowledge on the symptoms of pregnancy-related complications. We found greater knowledge about signs of eclampsia and initiatives to be taken for different birth preparedness components among Aponjon service-users compared to non-users. Thus, mHealth interventions have the potential to sensitize women about the second major cause of maternal death and promote good practices around the time of delivery, which is critical for saving the lives of the mother and her newborn.

PNC attendance, which begins $1 \mathrm{~h}$ after the delivery through 6 weeks post-partum [12], promotes healthy behaviors, danger sign recognition, and family planning practices. PNC also promotes extra care needed for lowbirth-weight babies or babies born to HIV-positive mothers and babies requiring other specialized care [12]. Missing a PNC attendance contributes to maternal morbidity and mortality [8]. In our study, Aponjon increased knowledge of where to seek PNC, although it did not increase PNC attendance.

Vitamin A deficiency is a significant public health problem in Africa and South-East Asia, as it can cause Nyctalopia and may increase the risk of death and sickness from childhood viral infections, like measles [13]. In our study, we found $24 \%$ of Aponjon serviceusers, compared to $16 \%$ of non-users, had taken vitamin A within 7 days of delivery, and the difference was statistically significant. While this is an improvement, as the majority of women in both the groups did not report taking vitamin $\mathrm{A}$, other interventions are also needed.

In our study, none of the individual indicators around behaviors for newborn care was associated with the use of Aponjon services. However, we did see some improvement in behavior around newborn care among the Aponjon users who subscribed to the service for more than 3 months and had a good pattern of receiving and listening to messages.

Only about 8 and $11 \%$ of our study population used Aponjon for at least 3 months during pregnancy and after delivery respectively. There was also substantial variation in the subscription to Aponjon among the four study areas. Relatively higher subscription rates in rural Brahmanbaria district was due to strong networking with implementation partners for promotion of Aponjon and a relatively longer duration of the intervention in that area. The challenge that the Aponjon program faced was a low subscription rate in the slum areas. A complementary qualitative study confirmed that health workers tended to choose relatively educated women from welloff families for the subscription to avoid concerns regarding the costs of the service [14]. Innovative programmatic efforts are needed for increasing the subscription rates in slum areas. To bring more poor women under the network, the program should rethink further enhancing the current pricing system (for subscribers with income below BDT 4000 or education level below the 5th grade, it costs BDT 1.00 per message/min; and, for subscribers from households headed by female or day-laborer the service is provided free of charge) for a safety-net program. The selection process of the clients for discounted pricing also should be reviewed to ensure that poor clients can benefit.

Missing the calls and/or not listening to messages carefully detracted from the positive effect of the intervention. As women reported not being able to listen due to other household obligations, initiatives should be taken by Aponjon to determine the best time of day to send messages, perhaps allowing users to select preferred time for receipt of messages to allow for different work/household schedules. Further, some incentivized mechanism could be built into the Aponjon package, such as discounted call rates for attaining a high score in knowledge tests to increase the motivation to listen to all messages carefully. For increased accessibility, the program could consider offering low-cost or used phones to individuals who do not own phones. By the end of November 2018, in Bangladesh, the total number of mobile phone subscriptions had reached 157 million, and this number is increasing daily [15]. Accessibility of mobile phones among new mothers in our study was also quite high. About $61 \%$ of the mothers owned a mobile phone, and nearly $37 \%$ had access to other's phones. These figures demonstrate the huge potential for using mobile phone for awareness raising for $\mathrm{MNH}$ in Bangladesh. On the other hand, Bangladesh is one of 57 countries with a severe shortage of trained doctors, paramedics, nurses, and midwives, [16] and any mHealth interventions must be combined with strengthening the presence of trained providers.

As the use of cell phones is increasing rapidly, there is an opportunity to improve health outcomes through the use of mHealth. The Bangladeshi Government has a mandate to establish 'Digital Bangladesh', and mHealth is a priority for health service delivery [17]. It is also worthwhile exploring the benefits of mHealth technology in reducing maternal and neonatal morbidity and morbidity. For about a quarter of the population of the country living below poverty level, who no longer 
consider mobile phones a luxury item [17], mHealth may be a mechanism to improve $\mathrm{MNH}$ outcomes.

\section{Limitations of the study}

This study had a number of limitations. Our outcome measures were knowledge and self-reported behaviors, which can be biased measures. Further, while we adjusted for hypothesized confounders through the use of PSM and multivariable regression, our results may be biased with residual confounding. Women who maintained their Aponjon subscription for 3 or more months may have had higher baseline knowledge prior to the subscription; however, the fact that listening to the messages carefully was associated with higher knowledge suggests that the messages themselves may have contributed to improved knowledge and practice. Finally, we were not able to test for the effect of exposure to Aponjon services in urban and rural areas separately.

\section{Conclusions}

Our research found that using Aponjon services for at least 6 months during pregnancy was associated with increased knowledge and positive behaviors during pregnancy, as well as knowledge of newborn healthcare after delivery. Overall, reporting a good pattern of using Aponjon services (receiving a minimum of 3 messages per month and listening to all messages carefully) was associated with increased knowledge as well as practices for both maternal and newborn health. A shorter exposure (i.e. 3-5 months), despite having a good use pattern of Aponjon service was not associated with these outcomes. Reasons for not receiving and carefully listening to all of the messages should be further explored and, accordingly, programmatic initiatives should be taken to overcome these problems for greater benefit of the intervention. Furthermore, future research should assess the impact of the use of Aponjon services on $\mathrm{MNH}$ outcomes, rather than knowledge and practice.

\section{Additional file}

Additional file 1: Study questionnaires. (ZIP $380 \mathrm{~kb}$ )

\section{Abbreviations}

ANC: Antenatal Care; Cl: Confidence Interval; MNH: Maternal and Newborn Health; OR: Odds Ratio; PNC: Postnatal Care; PSM: Propensity Score Matching

\footnotetext{
Acknowledgements

We are grateful to Dnet for allowing us to evaluate their Aponjon mHealth program. We also acknowledge the contribution of Dr. Lumbini Roy for her support during development of the research proposal and its implementation. Thanks to Ms. Shajratul Alam for her support in data analysis.

Authors' contributions

MEC conceptualized the evaluation plan and drafted the manuscript. SIS analyzed data, interpreted the results and contributed to writing the
}

manuscript. HEJ critically reviewed and contributed to writing the manuscript. All of the authors have read and approved the final version of the manuscript.

\section{Authors' information}

The corresponding author MEC is a Scientist and affiliated with the International Centre for Diarrhoeal Disease Research, Bangladesh (icddr,b), Dhaka, Bangladesh. SIS is a researcher and was affiliated with icddr,b as an intern during development of this paper. HEJ is faculty in the Dept. of Epidemiology and Biostatistics at the CUNY Graduate School of Public Health \& Health Policy, New York, USA.

\section{Funding}

This study was fully funded by the United States Agency for International Development (USAID) under the TRAction project to icddr,b through University Research Co., LLC (URC), Sub-agreement No. FY11-G04-699 under Cooperative Agreement No. GHS-A-00-09-00015-00. icddr,b is also thankful to the governments of Bangladesh, Canada, Sweden, and the UK, for providing support to its core fund. The funders did not have any role in the design of the study and collection, analysis, and interpretation of data and in writing the manuscript.

\section{Availability of data and materials}

The detailed dataset is available with MEC, the Principal Investigator of the main study. A copy of the original data is also stored in the data archive of icddr,b. These data are not publicly available. However, non-identifiable data can be accessed upon request subject to approval of the Research Administration Department of icddr,b.

\section{Ethics approval and consent to participate}

Ethical approval to conduct the study was obtained from the Ethics Review Committee of the International Centre for Diarrhoeal Disease Research, Bangladesh (icddr,b). Informed written consents were obtained from each of the respondents before their participation in the study.

\section{Consent for publication}

Consent for publishing non-identifiable data was obtained from each of the study participants.

\section{Competing interests}

The authors declare that they have no competing interests.

\section{Author details}

${ }^{1}$ International Centre for Diarrhoeal Disease Research, Bangladesh (icddr,b), 68 Shaheed Tajuddin Ahmed Sarani, Mohakhali, Dhaka 1212, Bangladesh. ${ }^{2}$ CUNY Graduate School of Public Health \& Health Policy, New York, USA.

Received: 5 January 2019 Accepted: 27 August 2019

Published online: 05 September 2019

\section{References}

1. Paul C, Miller R, Sithole R, Daggett M, Altman D, O'Byrne D. mHealth education: harnessing the Mobile revolution to bridge the Health Education \& Training gap in developing countries. Dublin: Irish Global Health Education Innovation Institute (iheed); 2011. Available from: https://www. mhealthknowledge.org/sites/default/files/20_iheedreport_2011.pdf. Accessed 31 Dec 2018

2. Hall AK, Cole-Lewis H, Bernhardt JM. Mobile text messaging for health: a systematic review of reviews. Annu Rev Public Health. 2015;36:393-415.

3. Cole-Lewis $H$, Kershaw T. Text messaging as a tool for behavior change in disease prevention and management. Epidemiol Rev. 2010;32:56-69.

4. Fedha T. Impact of Mobile telephone on maternal health service care: a case of Njoro division. Open J Prev Med. 2014;05:12.

5. Lund S, Nielsen BB, Hemed M, Boas IM, Said A, Said K, et al. Mobile phones improve antenatal care attendance in Zanzibar: a cluster randomized controlled trial. BMC Pregnancy Childbirth. 2014;14:29.

6. Lund S, Hemed M, Nielsen BB, Said A, Said K, Makungu MH, et al. Mobile phones as a health communication tool to improve skilled attendance at delivery in Zanzibar: a cluster-randomised controlled trial. BJOG. 2012;119: 1256-64. 
7. Kaewkungwal J, Singhasivanon P, Khamsiriwatchara A, Sawang S, Meankaew P, Wechsart A. Application of smart phone in "better border healthcare program": a module for mother and child care. BMC Med Inform Decis Mak. 2010;10:69.

8. Adanikin Al, Awoleke JO, Adeyiolu A. Role of reminder by text message in enhancing postnatal clinic attendance. Int J Gynaecol Obstet. 2014;126:179-80

9. Jiang $H$, Li M, Wen $L M, H u Q$, Yang $D, H e G$, et al. Effect of short message service on infant feeding practice: findings from a community-based study in Shanghai, China. JAMA Pediatr. 2014;168:471-8.

10. D'Agostino RB Jr. Propensity score methods for bias reduction in the comparison of a treatment to a non-randomized control group. Stat Med. 1998;17:2265-81.

11. Watkins SC, Robinson A, Dalious M. Evaluation of the information and communications technology for maternal, newborn and child health project. Malawi; 2013. Available from: http://www.villagereach.org/wpcontent/uploads/2017/07/ICT_for_MNCH_Report_131211md_FINAL.pdf. Accessed 31 Dec 2018

12. Mrisho M, Obrist B, Schellenberg JA, Haws RA, Mushi AK, Mshinda $H$, et al. The use of antenatal and postnatal care: perspectives and experiences of women and health care providers in rural southern Tanzania. BMC Pregnancy Childbirth. 2009;9:10.

13. Oliveira JM, Allert R, East CE. Vitamin A supplementation for postpartum women. Cochrane Database Syst Rev. 2016;(3):CD005944. https://doi.org/1 0.1002/14651858.CD005944.pub3.

14. Chowdhury ME, Khan R. Evaluating accessibility, acceptability and effectiveness of Aponjon mobile health messaging for improved maternal and newborn health behaviors and practices in Bangladesh. Dhaka: International Centre for Diarrhoeal Disease Research, Bangladesh (icddr,b; 2016

15. Bangladesh Telecommunication Regulatory Commission (BTRC). Mobile phone subscribers in Bangladesh, 2018. Available from: http://www.btrc.gov. bd/content/mobile-phone-subscribers-bangladesh-november-2018. Accessed 31 Dec 2018

16. World Health Organization. WHO Bangladesh country cooperation strategy 2008-2013. Bangladesh. India; 2007. Available from: http://www. searo.who.int/bangladesh/publications/ccs_ban_2008-2013.pdf?ua=1. Accessed 31 Dec 2018

17. Ahmed T, Lucas H, Khan AS, Islam R, Bhuiya A, Iqbal M. eHealth and mHealth initiatives in Bangladesh: a scoping study. BMC Health Serv Res. 2014; $14: 260$

\section{Publisher's Note}

Springer Nature remains neutral with regard to jurisdictional claims in published maps and institutional affiliations.

Ready to submit your research? Choose BMC and benefit from:

- fast, convenient online submission

- thorough peer review by experienced researchers in your field

- rapid publication on acceptance

- support for research data, including large and complex data types

- gold Open Access which fosters wider collaboration and increased citations

- maximum visibility for your research: over $100 \mathrm{M}$ website views per year

At $\mathrm{BMC}$, research is always in progress.

Learn more biomedcentral.com/submissions 